\title{
Maximum Metabolism and Thermoregulation in Laboratory Mice
}

\author{
Andrzej GORECKI \& Zofia KANIA
}

\begin{abstract}
Górecki A. \& Kania Z., 1986: Maximum metabolism and thermoregulation in laboratory mice. Acta theriol., 31, 7: 97-105 [With 2 Tables \& 3 Figs.]

Resting metabolism rate (RMR) was measured in adult white mice at various temperatures ranging from 32 to $-10^{\circ} \mathrm{C}$. At $0^{\circ} \mathrm{C}$ and $20^{\circ} \mathrm{C}$ the RMR measurements in normal air were followed by measurements where a mixture of $80 \% \mathrm{He}$ and $20 \% \mathrm{O}$, was used to induce maximum thermogenesis. The maximum metabolism in $\mathrm{He}-\mathrm{O}_{2}\left(8.3 \mathrm{ccmO}_{2} / \mathrm{g} \times \mathrm{hr}\right)$ was observed at $20^{\circ} \mathrm{C}$, while in normal air the highest values $(7.9 \mathrm{ccm}$ $\mathrm{O}_{2} / \mathrm{g} \times \mathrm{hr}$ ) were noted at 10 and $5^{\circ} \mathrm{C}$. The high level of metabolism was maintained only by 5 to 15 minutes. Constant rectal body temperature was maintained only within rage of ambients between 32 and $10^{\circ} \mathrm{C}$. At $-10^{\circ} \mathrm{C}$ the body temperature dropped to its lowest value $\left(20.4^{\circ} \mathrm{C}\right)$.

[Department of Animal Ecology, Jagiellonian University, Karasia 6, 30-060 Kraków, Poland]
\end{abstract}

\section{INTRODUCTION}

The values of metabolism in animals may vary within wide limits. The lower limit - the basal metabolism rate (BMR) is regarded by many as an indicator of an overall rate of energy expenditure, activity, even fitness, or as coefficient of reproduction (McNab, 1980). The upper limit is much less known though it may have a high survival value e.g. at very low ambients when heat losses are high or during a forced escape. The maximum metabolism measured in this study is represented by a maximum oxygen consumption utilized for generation of heat in thermogenesis (Wang, 1978; Abbots \& Wang, 1980) in contrast to the maximum oxygen consumption attained during a physical effort (Taylor, 1982; Taylor et al., 1981).

The maximum oxygen consumption measured in several species of mammals exceeded their corresponding BMR's by six to ten times (Pasquis et al., 1970; Rosenman et al., 1975; Wickler, 1980; Dawson \& Dawson, 1982). The rodents can increase their rates of metabolism within narrower limits than larger mammals. It is brought about by their relatively high resting metabolism rate or by an ability to incur oxygen debt. Acclimatization is known to serve as an important factor in widening the range of ambients within which animals can accelerate

${ }^{1}$ Badania prowadzone $\mathrm{w}$ ramach problemu MR.II.15 koordynowanego przez Instytut Ekologii PAN.

7 - Acta Theriologica 
their metabolism. The rodents that were acclimatized to low temperatures acquire both higher tolerance and resistance to cold. Such rodents may also attain higher values of the maximum metabolism (Pasquis et al., 1970). Not too much is so far known about a maximum metabolism in the laboratory mice (Pasquis et al., 1970; Hart, 1971; Rosenman \& Morrison, 1974; Prothero, 1979).

The maximum metabolism may be elicited by forcing animals to make utmost physical efforts or by bringing ambient temperatures to as low as $-60^{\circ} \mathrm{C}$. More recent method of forcing animals into the maximum thermogenesis uses a helium-oxygen mixture for breathing instead of normal air. Such mixture has much higher heat conductivity than nitrogen-oxygen mixture and subsequently speeds up heat losses. Under such conditions it is possible to obtain the maximum rate of thermogenesis without resorting to very low temperatures. The method has been widely applied (Rosenman \& Morrison, 1974; Wang, 1980; Wickler, 1980). Grazienko \& Kalvin (1975) found no adverse effect of He on living organisms.

The aim of the study was to determine the level of maximum metabolism in laboratory mice and metabolism-related changes in rectal temperature.

\section{MATERIAL AND METHOD}

53 laboratory white mice (Mus musculus Linnaeus 1758) including 32 females and 21 males were employed in experiments. Their body weights ranged from 25 to $43 \mathrm{~g}$. The animals were maintained in our animal facility at a neutral $20 \pm 2{ }^{\circ} \mathrm{C}$, and a natural light regime. Oat and wheat grain, grannulated rodent food, and water were generally available.

The first series of experiments the BMR measurements were carried out. (The only deviation from the condition required of BMR was that the animals were not in post-absorbtive state). The resting metabolism rates (RMR) were measured in natural atmosphere at $32,28,23,20,10,5,0$ and $-10^{\circ} \mathrm{C}$. In the second series of experiments a maximum rate of thermogenesis was measured at $20^{\circ} \mathrm{C}$ and $0^{\circ} \mathrm{C}$ in air that was replaced by a mixture of $80 \%$ He and $20 \% \mathrm{O}_{2}$ henceforth denoted as $\mathrm{He}-\mathrm{O}_{2}$ (Cygan, 1984).

The series of 40-minute long measurements were carried out in a closed-circuit manometric respirometer of Kalabukhov-Skvortzov system, in chambers of 1 litre capacity (Górecki, 1975). The mice were placed in wire net cages $(8.5 \times 4 \times 4 \mathrm{~cm})$ that prevented most movements. In experiments with $\mathrm{He}-\mathrm{O}_{2}$ during initial 20-minutes animals were breathing air. Later the chamber was flushed with $10-15$ 1 of $\mathrm{He}-\mathrm{O}_{2}$ until the air was completely replaced, then the metabolism was again measured during 20 minute run.

Rectal temperatures were taken with electronic probe accurate to the nearest $1^{\circ} \mathrm{C}$ within no more than $20-40 \mathrm{~s}$ after removing the animal from the chamber.

The rectal temperatures were not primarily taken in series of experiments carried out at 5 and $10^{\circ} \mathrm{C}$. To bridge that gap in data thame animals were 
exposed to the same temperatures in simulated experimental conditions two weeks later. Mean while their body weights changed a little as shown in Table 1 .

Table 1

Oxygen consumption and body temperature in laboratory mice at various ambient temperatures.

\begin{tabular}{|c|c|c|c|c|}
\hline $\begin{array}{l}\text { Ambient } \\
\text { temp., }{ }^{\circ} \mathrm{C}\end{array}$ & $\mathbf{N}$ & $\begin{array}{l}\text { Body } \\
\text { weight } \pm S D\end{array}$ & $\begin{array}{l}\text { Oxygen consump. } \\
\mathrm{ccm} \mathrm{O}_{2} / \mathrm{g} \times \mathrm{hr} \pm \mathrm{SD}\end{array}$ & $\begin{array}{l}\text { Body } \\
\text { temp. } \pm S D\end{array}$ \\
\hline & & \multicolumn{3}{|c|}{ Measurements in air } \\
\hline 32 & 30 & $26.8 \pm 5.6$ & $3.78 \pm 0.53$ & $36.4 \pm 0.6$ \\
\hline 28 & 30 & $27.0 \pm 4.7$ & $3.41 \pm 0.56$ & $35.6 \pm 0.7$ \\
\hline 25 & 30 & $24.1 \pm 5.6$ & $3.62 \pm 0.49$ & $36.3 \pm 1.0$ \\
\hline \multirow[t]{2}{*}{20} & 18 & $27.9 \pm 2.5$ & $5.27 \pm 0.86$ & $36.5 \pm 0.9$ \\
\hline & 20 & $28.2 \pm 2.2$ & $7.93 \pm 0.78$ & - \\
\hline \multirow[t]{2}{*}{10} & 14 & $30.2 \pm 5.1$ & - & $35.7 \pm 1.1$ \\
\hline & 19 & $28.4 \pm 2.6$ & $7.93 \pm 0.76$ & - \\
\hline 5 & 14 & $32.1 \pm 2.2$ & - & $32.2 \pm 2.0$ \\
\hline 0 & 30 & $29.8 \pm 4.9$ & $6.60 \pm 0.70$ & $31.7 \pm 2.1$ \\
\hline \multirow{3}{*}{$\begin{array}{r}-10 \\
0\end{array}$} & 30 & $35.7 \pm 3.9$ & $5.10 \pm 1.41$ & $20.4 \pm 3.5$ \\
\hline & 24 & $37.8 \pm 7.1$ & $6.11 \pm 1.12$ & - \\
\hline & & \multicolumn{3}{|c|}{ Measurements in $\mathrm{He}-\mathrm{O}_{2}\left(80 \% \mathrm{He}, 20 \% \mathrm{O}_{2}\right)$} \\
\hline & 24 & $37.8 \pm 7.1$ & $7.31 \pm 1.59$ & $22.8 \pm 2.5$ \\
\hline$\therefore \quad 20$ & 17 & $28.5 \pm 2.4$ & $8.32 \pm 0.73$ & $35.0 \pm 0,9$ \\
\hline
\end{tabular}

\section{RESULTS}

\subsection{Basal Metabolism Rate and Thermoregulation Curve}

At 25,28 and $32^{\circ} \mathrm{C}$ differences in oxygen consumption values were negligible, although it can be noted that a thermoneutral zone lies almost exactly around $28^{\circ} \mathrm{C}\left(3.4 \mathrm{ccm} \mathrm{O}_{2} / \mathrm{g} \times \mathrm{hr}\right)$ with two slightly higher values for 25 and $32^{\circ} \mathrm{C}$ (Fig. 1). Hence the value of metabolism obtained at $28^{\circ} \mathrm{C}$ was assumed as basal (BMR).

At lower ambients the metabolism measures in air increased rapidly (Table 1, Fig. 1). In 10 and $5^{\circ} \mathrm{C}$ the values obtained were identical at $7.9 \mathrm{ccm} \mathrm{O}_{2} / \mathrm{g} \times \mathrm{hr}$. At $0^{\circ} \mathrm{C}$ metabolism value started to fall and reached its minimum level at $-10^{\circ} \mathrm{C}$ (below $5.1 \mathrm{~cm} \mathrm{O}_{2} / \mathrm{g} \times \mathrm{hr}$ ). These values were obtained for group of animals with body weights that were slightly higher and more variable than in other groups.

The highest value of metabolism measured in $\mathrm{He}-\mathrm{O}_{2}$ atmosphere was noted at $20^{\circ} \mathrm{C}\left(8.3 \mathrm{ccm} \mathrm{O}_{2} / \mathrm{g} \times \mathrm{hr}\right)$ and was slightly lower at $0^{\circ} \mathrm{C}$. This phenomenon was related to changes in body temperatures that are described later in the paper. It was also possible to follow timing of spells of high metabolism in animals exposed to low ambients. The respirometer used in the experiment allowed monitoring the oxygen con?, sumption in 5 -minute intervals. In $0^{\circ} \mathrm{C}$ the highest value $(7.00 \mathrm{ccm}$ 


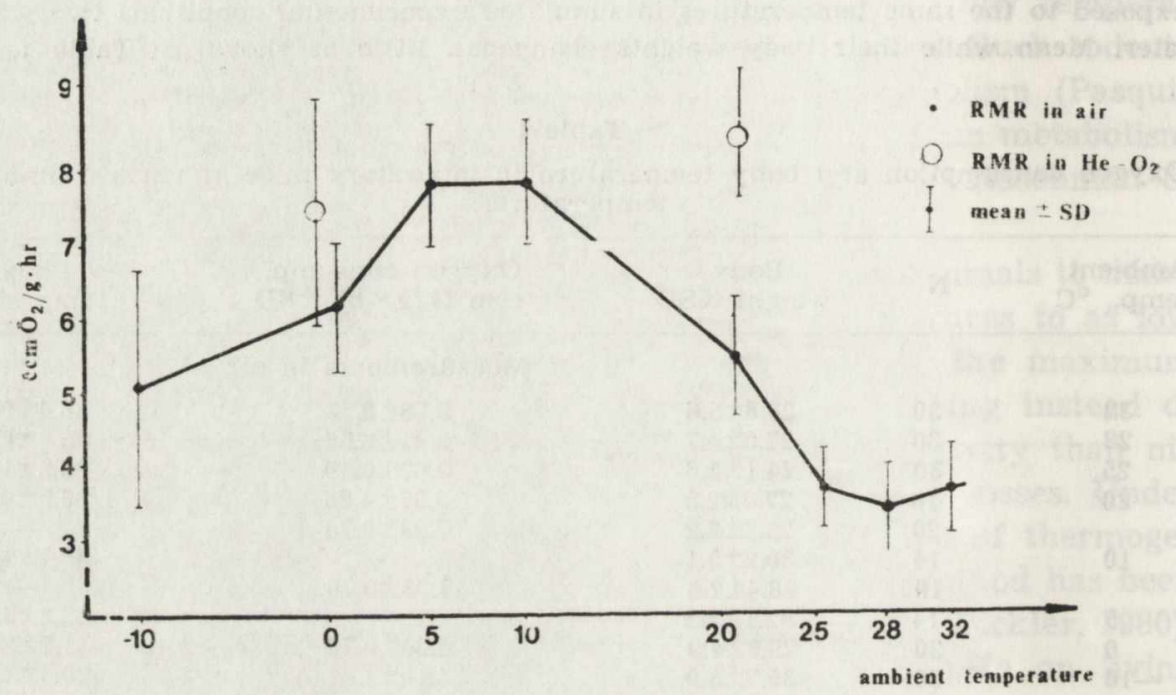

Fig. 1. Thermoregulation curve for laboratory mice.

$\mathrm{O}_{2} / \mathrm{g} \times \mathrm{hr}$ ) was noted after 15 minutes which almost constant rate in following periods (Fig. 2). At $-10^{\circ} \mathrm{C}$ the highest metabolism rate was attained in first 5 minutes $\left(6.6 \mathrm{~cm} \mathrm{O}_{2} / \mathrm{g} \times \mathrm{hr}\right)$ falling after next 5 minutes to $5.5 \mathrm{ccm} \mathrm{O}_{2} / \mathrm{g} \times \mathrm{hr}$ with that decreasing tendency maintained till the end of measurement (Fig. 2).

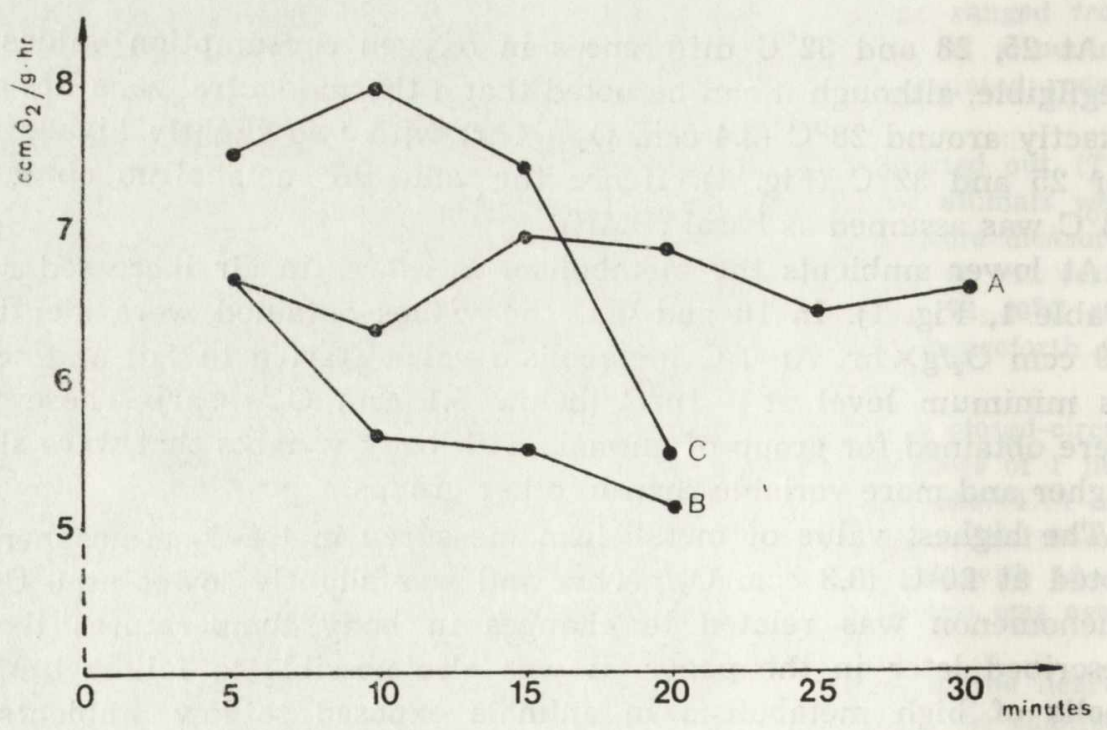

Fig. 2. Metabolism rates in laboratory mice: at $0^{\circ} \mathrm{C}$ in air (A), at $-10^{\circ} \mathrm{C}$ in air (B), at $0^{\circ} \mathrm{C}$ in $\mathrm{He}-\mathrm{O}_{2}$ atmosphere (C). 
In experiments at $0^{\circ} \mathrm{C}$ where the $\mathrm{He}-\mathrm{O}_{2}$ replaced the air the metabolism value reached $7.3 \mathrm{ccm} \mathrm{O}_{2} / \mathrm{g} \times \mathrm{hr}$ in first 5 -minute period to rise to maximum value of $7.9 \mathrm{ccm} \mathrm{O}_{2} / \mathrm{g} \times \mathrm{hr}$ in the next period and later drop rapidly. At $20^{\circ} \mathrm{C}$ no such pattern of changes was observed.

\subsection{Body Temperature}

Within the thermoneutral zone of ambients the rectal temperature was almost constant (Table 1, Fig. 3). When facing lower temperatures

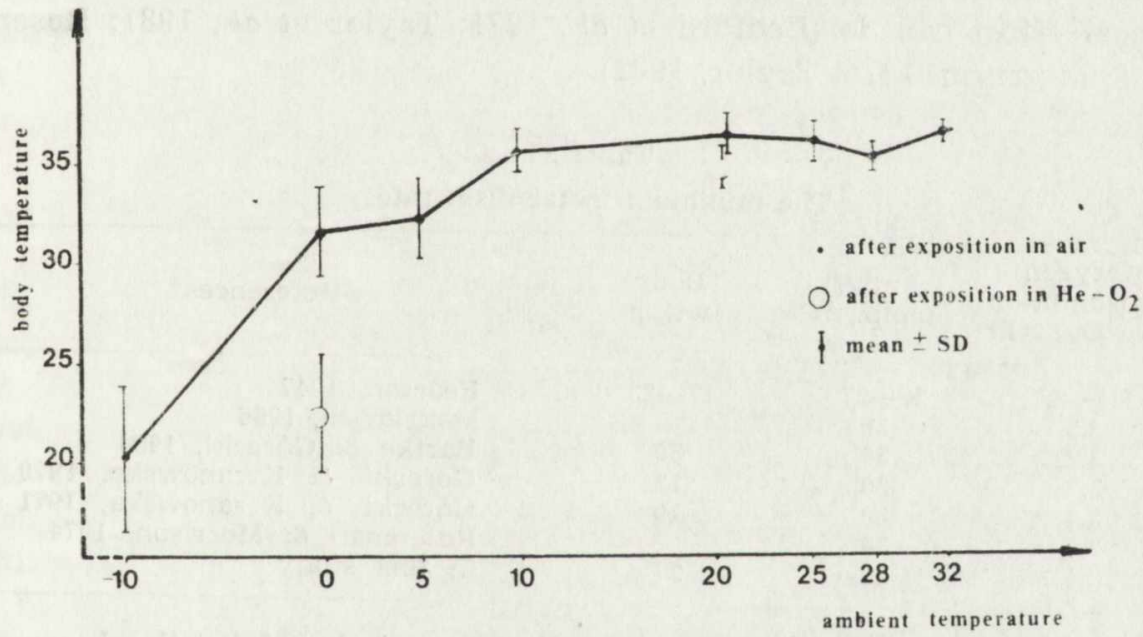

Fig. 3. Changes in rectal body temperatures at various ambients.

the mice could still maintain homeothermy. At $10^{\circ} \mathrm{C}$ the rectal temperature was $35.7^{\circ} \mathrm{C}$ i.e. still close to values obtained at higher ambient temperatures. At $5^{\circ} \mathrm{C}$ the body temperature dropped to $32.1^{\circ} \mathrm{C}$ and at $0^{\circ} \mathrm{C}$ to $31.7^{\circ} \mathrm{C}$ to obtain its lowest value of $20.4^{\circ} \mathrm{C}$ at $-10^{\circ} \mathrm{C}$ of ambient temperatures. In experiments that involved breathing in $\mathrm{He}-\mathrm{O}_{2}$ at $0^{\circ} \mathrm{C}$ the rectal body temperature was again low $\left(22.8^{\circ} \mathrm{C}\right)$. At $20^{\circ} \mathrm{C}$ the mice maintained constant body temperature of $35.0^{\circ} \mathrm{C}$. All the mice exposed to $-10^{\circ} \mathrm{C}$ and those subjected to breathing $\mathrm{He}-\mathrm{O}_{2}$ survived the experiments.

\section{DISCUSSION}

The minimum metabolism in Mus musculus has been determined in several studies (Table 2). The ratio between maximum and minimum (determined in short periods of time) was 3.2. The lowest values of this ratio were reported by Pearson (1947) durinf $24 \mathrm{hr}$ trials. His experiments were however conducted at relatively high ambient temperatures. 
Much higher values were reported by Pasquis et al., (1970). They found the maximum metabolism in white mice to exceed six fold the minimum one, and in larger rodents, like the rat, Guinea pig, and hamster, by six to seven times. The highest value (6.3) was obtained by Hart (1971) for Mus musculus. The discrepancy in these results might have originated from differences in methods by which the maximum metabolism was induced or from various thermal conditions in which the animals were kept prior to the experiments. In general the maximum thermogenesis exceeds the minimal rate (BMR) by less than the metabolism of physical effort can do (Bedford et al., 1971; Taylor et al., 1981; Rosenman \& Morrison, 1974; Taylor, 1982).

Table 2

The minimum metabolism rate.

\begin{tabular}{|c|c|c|c|}
\hline $\begin{array}{c}\text { Oxygen } \\
\text { consumption } \\
\text { ccm } \mathrm{O}_{2} / \mathrm{g} \times \mathrm{hr}\end{array}$ & $\begin{array}{l}\text { Ambient } \\
\text { temp., }{ }^{\circ} \mathrm{C}\end{array}$ & $\begin{array}{l}\text { Body } \\
\text { wt., g }\end{array}$ & References \\
\hline $2.1-2.7$ & $26-27$ & $17-23$ & Pearson, 1947 \\
\hline 2.3 & 30 & & Mokrievich, 1966 \\
\hline 3.2 & 30 & 30 & Bartke \& Górecki, 1968 \\
\hline 3.2 & 30 & 12 & Gorecki \& Krzanowska, 1970 \\
\hline 3.4 & 30 & 19 & Górecki \& Krzanowska, 1971 \\
\hline 2.0 & 30 & & Rosenman \& Morrison, 1974 \\
\hline 3.4 & 28 & 27 & in this study \\
\hline
\end{tabular}

In this study the maximum metabolism was induced by the lowered or by breathing $\mathrm{He}-\mathrm{O}_{2}$ mixture instead of normal air. The maximum metabolism was found by Rosenman \& Morrison (1974) to occur at various temperatures in various species of rodents. For M. musculus of average body weight of $29.5 \mathrm{~g}$ the maximum metabolism in $\mathrm{He}-\mathrm{O}_{2}$ atmosphere $\left(11.1 \mathrm{~cm} \mathrm{O} \mathrm{O}_{2} / \mathrm{g} \times \mathrm{hr}\right)$ was found to occur at $7^{\circ} \mathrm{C}$. In this study the maximum value of metabolism in $\mathrm{He}_{-} \mathrm{O}_{2}$ atmosphere was $7: 3 \mathrm{ccm} \mathrm{O} / \mathrm{g} \times \mathrm{hr}$ at $0^{\circ} \mathrm{C}$ and $8.3 \mathrm{~cm} \mathrm{O} / \mathrm{g} \times \mathrm{hr}$ at $20^{\circ} \mathrm{C}$ (Table 1, Fig. 1). Rosenman \& Morrison (1974) extrapolated the thermoregulation curve from their experimental results and determined that the maximum metabolism should occur in $M$. musculus at around $-14^{\circ} \mathrm{C}$. The present: stu$\mathrm{dy}$ revealed that the breathing $\mathrm{He}-\mathrm{O}_{2}$ atmosphere at $0^{\circ} \mathrm{C}$ brought about a significant decrease in body temperature (Fig. 3) similar to that taking place in normal air at $-10^{\circ} \mathrm{C}$. Thus it may be assumed that the measurement in $\mathrm{He}-\mathrm{O}_{2}$ at $0^{\circ} \mathrm{C}$ corresponds roughly with a measurement in air at around $-9^{\circ} \mathrm{C}$ (Fig. 3).

The body temperature measurements indicate that the mice used in this experiment entered a hypothermy as early as at $10^{\circ} \mathrm{C}$. It deepened with decrease at ambient temperatures. Similar, transitional range of 
temperature was found by Mokrievich (1966). Hence there is some ground for assuming that the maximum metabolism range should fall within this range of ambients. Górecki \& Krzanowska (1971) studying the white mice of somewhat lesser body weight (around $19 \mathrm{~g}$ ), but kept under similar conditions as those used in this study, obtained fairly high values of metabolism $\left(7.63 \mathrm{ccm} \mathrm{O}_{2} / \mathrm{g} \times \mathrm{hr}\right)$ at $10^{\circ} \mathrm{C}$. Similar results (8.65 $\mathrm{ccm} \mathrm{O}_{2} / \mathrm{g} \times \mathrm{hr}$ ) were obtained by Bartke \& Górecki (1968) for white mice of larger body weight $(23 \mathrm{~g})$.

Pasquis et al. (1970) studied acclimatization as a factor that may enhance the ability to accelerate the heat production. After having been acclimatized to cold at $6^{\circ} \mathrm{C}$ the mice could attain the maximum metabolism at $-10^{\circ} \mathrm{C}$ while those acclimatized at $30^{\circ} \mathrm{C}$ did it at $-3^{\circ} \mathrm{C}$.

The maximum metabolism rate can usually be maintained only for a very limited period of time. When heat losses exceed the volume of its production, ensuing energy deficit must lead, sooner or later, to hypothermy. During the measurements taken in $\mathrm{He}-\mathrm{O}_{2}$ atmosphere at low temperatures the ability to keep a high level of metabolism varied. At the lowest temperature $\left(-10^{\circ} \mathrm{C}\right)$ the animals were able to keep that level for no more than 5 minutes after which a decrease in metabolism followed, accelerated with time.

Similar changes although with varied intensity were observed in other measurements in $\mathrm{He}-\mathrm{O}_{2}$ atmosphere. That confirmed observations made by Rosenman \& Morrison (1974). At $1^{\circ} \mathrm{C}$ in $\mathrm{He}_{-} \mathrm{O}_{2}$ atmosphere the maximum heat production was maintained only by 5 minutes followed by its drop and hypothermy.

It is then reasonable to assume that a long (continuing even for many generations) acclimatization to standard temperature $\left(20^{\circ} \mathrm{C}\right)$ maintained at animal facilities has modified the physiological response of white mice to thermal stimuli. The results obtained in this study may be thus quite specific and, accordingly might not relate to the physiology of ther rodents of similar size, particularly wild ones.

\section{REFERENCES}

1. Abbots B. \& Wang L. C. H., 1980: Seasonal thermogenic capacity in a hibernator, Spermophilus richardsonii. .T. comp. Physiol., 140: 235-240.

2. Bartke A. \& Górecki A., 1968: Oxygen consumption by obese yellow mice and their normal littermates. Am. J. Physiol., 214: 1250-1252.

3. Bedford T. G., Tipton C. M., Wilson N. C., Oppliger R. A. \& Gisolfi C. V., 1979: Maximum oxygen consumption of rates and its changes with various experimental procedures. J. appl. Physiol., Respirat. Environ. Exercise Physiol., 47: 1278-1283.

4. Cygan T., 1984: Seasonal changes in thermoregulation and maximum metabolism in the yellow-necked field mouse. Acta theriol., 30: 115-130. 
5. Dawson T. J. \& Dawson W. R., 1982: Metabolic scope and conductance in response to cold of some daysuird marsupials and Australian rodents. Comp. Biochem. Physiol., 71A: 58-64.

6. Gazenko O. G. \& Kalvin M., 1975: Osnovy kosmičeskoj biologii i mediciny. Izd. Nauka: 1-63. Moskva.

7. Górecki A., 1975: Kalabukhov-Skvortsov respirometer and resting metabolic rate measurements [In: "Methods for ecological bioenergetics", Eds. Grodziński W., Klekowski R. Z. \& Duncan A.]. IBP Handbook no. 24. Blackwell Sci. Publ. Oxford: $309-313$. London, Edinburgh, Melbourne.

8. Górecki A. \& Krzanowska H., 1970: Oxygen consumption in two inbred mouse strains and $F_{1}$ hybrids. Bull. Acad. Pol. Sci., Cl. II, 18: 115-119.

9. Górecki A. \& Krzanowska H., 1971: Effect of cross-foster nursing on oxygen consumption in two inbred mouse strains. Bull. Acad. Pol. Sci. Cl. II, 19: $611-615$.

10. Hart J. S., 1971: Rodents [In: "Comparative physiology of thermoregulation", Ed. G. C. Whitow]. Acad. Press, 2: 2-149.

11. McNab B. K., 1980: Food habits, energetics, and the population biology of mammals. Am. Nat., 116: 106-124.

12. Mokrievich N. A., 1966: Ekologo-fizjologiČeskije osobennosti obyknovennych polievok (Microtus arvalis) i domovych myšej (Mus musculus) v volzsko-ural skich peskach. Zool. Ž., 14: 447-451.

13. Pasquis P., Lacaisse A. \& Dejours P., 1970: Maximal oxygen uptake in four species of small mammals. Resp. Physiology, 9: 298-309.

14. Pearson O. P., 1947: The rate of metabolism of some small mammals. Ecology, 28: $127-145$.

15. Prothero J. W., 1979: Maximal oxygen consumption in various animals and plants. Biochem. Physiol., 64: 463-466.

16. Rosenmann M. \& Morrison P., 1974: Maximum oxygen consumption and heat loss facilitation in small homeotherms by $\mathrm{He}-\mathrm{O}_{2}$. Am. J. Physiol., 226: 490-496.

17. Rosenmann M., Morrison P. \& Feist D., 1975: Seasonal changes in the metabolic capacity of red-backed voles. Physiol. Zool., 48: 303-310.

18. Taylor C. R., Maloiy G. M., Weibel E. R., Langman V. A., Kamau J. M., Seehermann H. J. \& Heglund N. C., 1981: Design of the mammalian respiratory system. III. Scaling maximum aerobic capacity to body mass: wild and domestic animals. Respir. Physiol., 44: 25-37.

19. Taylor C. R., 1982: Scaling limits of metabolism of body size: implications for animals design [In: "A companion to animal physiology", Eds. C. R. Taylor, K. Johansen \& L. Bolis]. Cambridge Univ., Press: 161-180. Cambridge.

20. Wang L. C., 1978: Factors limiting maximum cold induced heat production. Life Sciences, 23: 2089-2098.

21. Wang L. C., 1980: Modulation of maximum thermogenesis by feeding in the white rat. J. appl. Physiol., Respirat. Environ. Exercies Physiol., 49: 975-978.

22. Wickler S. J., 1980: Maximal thermogenic capacity and body temperatures of white-footed mice (Peromyscus) in summer and winter. Physiol. Zool., 53: $338-346$.

Accepted, July 10, 1985. 
Andrzej GORECKI i Zofia KANIA

\section{METABOLIZM MAKSYMALNY I TERMOREGULACJA MYSZY LABORATORYJNYCH}

\section{Streszczenie}

W temperaturach otoczenia od -10 do $32^{\circ} \mathrm{C}$ mierzono metabolizm spoczynkowy (RMR) myszy laboratoryjnych (Mus musculus Linnaeus, 1758). Pomiary wykonywano w respirometrze systemu zamkniętego. Oprócz pomiarów w powietrzu przeprowadzono $\mathrm{w}$ temp. 0 i $20^{\circ} \mathrm{C}$ dwudziestominutowe pomiary $\mathrm{w}$ atmosferze $80 \%$ $\mathrm{He}$ i $20 \% \mathrm{O}_{2}$. Taka mieszanina ma znacznie wyższe przewodnictwo cieplne niż powietrze, a jej zastosowanie pozwoliło na osiągnięcie maksymalnego metabolizmu w znacznie wyższych temperaturach otoczenia.

Strefę termoneutralną zaobserwowano $\mathrm{w} 28^{\circ} \mathrm{C}$, najniższy metabolizm w zakresie $5-10^{\circ} \mathrm{C}$ (Ryc. 1). Maksymalna termogeneza; wymuszona atmosfera $\mathrm{He}_{-} \mathrm{O}_{2}$ wystąpiła w $20^{\circ} \mathrm{C}$ o osiągnięła wartość $8.3 \mathrm{ccm} \mathrm{O}_{2} / \mathrm{g} \times \mathrm{hr}$ (Tabela 1, Ryc. 1). Zwierzęta przez różny okres czasu były zdolne utrzymywać wysoki metabolizm. (Ryc. 2).

Stała temperatura ciała byla utrzymywana od wysokich temperatur otoczenia: do $10^{\circ} \mathrm{C}$. W niższych temperaturach obserwowano wyraźny jej spadek dochodzący do $20.4^{\circ} \mathrm{C}$ po 40 -minutowych pomiarach $\mathrm{w}-10^{\circ} \mathrm{C}$ (Ryc. 3 ).

Eksperymenty jeszcze raz potwierdzily, że myszy laboratoryjne aklimatyzowane do warunków hodowlanych przez wiele pokoleń mają zupełnie zmodyfikowana odpowiedź na bodźce termiczne. Ich krzywa termoregulacji jest bowiem w porównaniu z dzikimi gryzoniami o podobnym ciężarze ciała stosunkowo stroma. 